\title{
An evaluation of the usability of glass and polypropylene fibers in SMA mixtures
}

\author{
TMA karışımlarında cam ve polipropilen elyaf kullanımının \\ değerlendirilmesi
}

\author{
Burak EVIRGEN ${ }^{*}$ (iD) Altan ÇETIN ${ }^{2}$ (iD), Asena KARSLIOĞLU ${ }^{3}$ (D) Ahmet TUNCAN $^{4}$ (iD) \\ 1,3,4 Department of Civil Engineering, Faculty of Engineering, Eskișehir Technical University, Eskişehir, Turkey. \\ burakevirgen@eskisehir.edu.tr, asenakarslioglu@eskisehir.edu.tr, atuncan@eskisehir.edu.tr \\ 2Department of Civil Engineering, Faculty of Engineering, Bartın University, Bartın, Turkey. \\ acetin@bartin.edu.tr
}

\begin{abstract}
The use of stone mastic asphalt (SMA) is generally preferred to combat the undulation problem of roads due to wheel rutting, which is considered to be the most serious deterioration of road superstructure under heavy vehicle loads and thermal conditions. This type of mixture has a high level of aggregate interaction and interlocking effect with a high bitumen ratio in order to increase the lifetime of pavements. Commonly, polymer modified bitumen or cellulosic fiber additives involving a bitumen modification process is favored during the application. In this study, the usability of mixture modification was investigated by adding glass and polypropylene fibers directly into the dry mixture, unlike bitumen modification process that is requiring two mixing stages. In total, 169 specimens were prepared using a gyratory compactor according to the superpave design method. Of these specimens, 120 were fiber added samples with a ratio from $0.1 \%$ to $0.8 \%$ by dry weight aggregate. The draindown resistance, resilient modulus and water susceptibility including indirect tensile strength values, were improved by the addition of glass and polypropylene fibers according to experimental results within a range of $0.6 \%$ to $0.8 \%$ generally. However, calculated strain results show that satisfactory creep values could not be obtained in terms of static and dynamic uniaxial tests. Despite the fact that higher displacement occurred, reflecting cracks were eliminated owing to ductile behavior.
\end{abstract}

Keywords: Stone mastic asphalt (SMA), Glass fiber, Polypropylene fiber, Resilient modulus, Bitumen draindown, Permanent deformation.

\begin{abstract}
Öz
Ağır tașıt yükleri ile ısıl șartlar altında yol üst yapısının en önemli bozulması olarak kabul edilen ve tekerlek izi nedeniyle meydana gelen ondülasyon problemiyle mücadele etmek için genellikle taş mastik asfalt (SMA) kullanımı tercih edilmektedir. Kaplama ömrünü arttırmak amacıyla bu tip karışımlar yüksek seviyede agrega etkileşimi ve kilitlenme etkisi ile yüksek bitüm oranı içermektedir. Uygulama sırasında çoğunlukla, polimer modifiye bitüm veya bitüm modifikasyonu uygulanmıș selülozik elyaf katkıları tercih edilmektedir. Bu çalıșmada, iki așama gerektiren bitüm modifikasyonunun aksine cam ve polipropilen tipi elyaflar direkt kuru karışıma eklenerek karıșım modifikasyonunun kullanılabilirliği araștırılmıștır. "Superpave" tasarım yöntemine göre yoğurmalı sıkıştırıcı kullanılarak toplam 169 numune hazırlanmıștır. Bu numunelerin 120 adedine kuru agrega ağırlı̆̆ının \%0.1'i ile \%0.8'i arasında elyaf eklenmiştir. \%0.6 ile \%0.8 arasında değișen cam ve polipropilen elyaf katkılı deney sonuçlarına göre; süzülme direnci, esneklik modülü ve su hassasiyeti içeren dolayl çekme dayanımı değerleri iyileştirilmiştir. Ancak, hesaplanan birim șekil değiştirme sonuçları statik ve dinamik tek eksenli testler açısından tatmin edici sünme değerlerinin elde edilemediğini göstermektedir. Daha yüksek deplasmanlar gerçekleșmesine rağmen, sünek davranıș nedeniyle yansıma çatlakları ortadan kaldırılmıştır.
\end{abstract}

Anahtar kelimeler: Taș mastik asfalt (TMA), Cam fiber, Polipropilen fiber, Esneklik modülü, Bitüm süzülme, Kalıcı deformasyon.

\section{Introduction}

Stone mastic asphalt (SMA) mixtures are developed and used in many countries around the world against rutting caused by studded tires. SMA has been used in Turkey since 1999 as a wearing surface against heavy traffic effects [1]. This is one research area aimed at improving the performance of bituminous mixtures including new methods and design details [2]. SMA mixtures have high performance in terms of durability and rutting resistance due to their high content of coarse aggregate and filler ratio as well as bitumen modification [3],[4]. Design, production and application of SMA mixture increase cost compared to conventional bitumen mixtures. One fundamental reason for this increment is the high temperature requirement in bitumen modification and production processes. In addition, a number of difficulties are encountered during the spreading and compaction stages, as well as the additional cost requirement of cellulosic fiber usage to prevent the draindown effect [5],[6].

Although polymer modification is used as the most popular bitumen modification method, the favorable effects of fiber additives in asphalt mixture modification are reported in the literature. Studies on the behavior of fiber added asphalt mixtures show that a respectable amount of enhancement can be realized against permanent deformation and fatigue cracking [7],[8]. Certain fibers, which have high tensile strength, improve the adhesive properties and tensile strength of asphalt mixtures. Therefore, the fiber addition process increases the resilient modulus, modulus of rigidity, rutting strength, moisture susceptibility, and resistance against freezing thawing cycles of bituminous mixtures or pavements while reducing reflection cracks because of changes in the

${ }^{*}$ Corresponding author/Yazışılan Yazar 
viscoelastic properties [9],[10]. Nowadays, glass and basalt originated fibers have been proposed instead of conventional polypropylene fibers. These new generation fibers have relatively high tensile strength, low elongation ratio and low working temperature requirements. Although the use of mentioned fibers is quite common in cement based concrete mixtures with the aim of increasing tensile strength and preventing crack formations, a limited number of studies have been found on the performance of SMA type of bituminous hot mixtures. Despite the fact that the use of fiber increases production costs in common mixtures, it is reasonable to use it as an alternative for expensive bitumen modification techniques. Using fibers in asphalt mixtures is more competitive compared with modified bituminous mixtures when considering technological development on fiber production and life span-performance relationships of asphalt pavements [11].

On the other hand, glass fiber addition to warm asphalt consisting of recycled asphalt pavement (RAP) improves the performance of mixtures against rutting and moisture susceptibility [12]. Aptahi et al. [13] studied the effect of hybrid use of polypropylene and glass fibers on the performance of asphalt concrete mixtures. The results show that hybrid modified mixtures can be confidently used in hot climate regions because of an increase in both voids and stability levels. Mahrez et al. [14],[15] state that resilient modulus and fatigue performance are greatly improved by increasing the amount of $20.0 \mathrm{~mm}$ long glass fibers. However, permanent deformations were negatively and unexpectedly affected under a dynamic creep loading test and Marshall Stability test. Another study shows that the addition of glass and polypropylene fibers according to different percentages, gives the best stability values among nylon, polyester, polypropylene and glass fiber [16]. Furthermore, glass fiber reinforcement improves the flexibility of mixtures without altering the optimum bitumen content and also prevents bleeding problems at high temperatures [17].

Fibers of basalt rock origin can be used to reinforce structural materials instead of carbon and glass fibers. In recent years, basalt fibers have been used to modify and reinforce asphalt mastic and asphalt mixtures [18],[19]. The addition of basalt fiber to the mastic directly increases the tensile strength, rigidity and fatigue resistance properties [20],[21]. Decreasing the length of fiber has positive effects on the rheological behavior of asphalt mixtures of constant fiber diameter due to the interaction area in the matrix [22]-[24].

Polypropylene fibers (PF) have been widely-used as an additive material to improve strength and to prevent crack formations in concrete [25],[26]. After studies were placed in the literature supporting the use of PP fibers in the modification of bitumen, a regulation for the use of PP fibers in high performance asphalt concrete was published in United States [27]. Previous studies suggest that the addition of PP fibers satisfies stability, while the other properties are kept within acceptable limits [28],[29]. An addition of thermoplastic materials, such as polyethylene (PE) and polypropylene inside bitumen, increases the rigidity and viscosity of a mixture around service temperature [30],[31]. The modification includes low density PE and PP and improves physical and rheological properties while decreasing penetration and viscosity [32],[33]. PP modified asphalt mixtures have a higher Marshall stability and indirect strength than non-modified asphalt mixtures generally [34]. Although fiber-modified mixtures are slightly stiffer, it is concluded that these have improved fatigue life, according to Huang and White [10].

In this study, it is investigated whether fiber modified SMA mixtures can be alternatively used instead of traditional design methods to especially improve rutting resistance. Different fiber types were used for this purpose, having high physical and mechanical properties, such as glass and polypropylene. Indirect tensile strength, stiffness, permanent deformation and moisture susceptibility tests were performed to evaluate the effects of the fiber content at an optimum bitumen rate, determined by the Superpave method. Fiber modified SMA mixtures were compared with traditional mixtures, for instance Styrene-Butadiene-Styrene (SBS) modified bitumen including specimens and cellulosic fiber added specimens. Moreover, design optimization was proposed for stone mastic asphalt mixtures modified by fibers.

\section{Material properties}

Aggregate, bitumen and filler are used as raw materials in ordinary asphalt mixtures. However, SBS modified bitumen or cellulosic fiber are generally used to provide resistance to draindown and to improve physical and mechanical behavior. Within this study glass fibers (GF) and polypropylene fibers $(\mathrm{PF})$ were used in addition to the aforesaid materials.

\subsection{Aggregate}

Selected mix gradation of used aggregate is shown in Table 1, according to the limit values of Type-I gradation for wearing surface mentioned in related specifications [1]. The physical properties of crushed limestone aggregate taken from a quarry located in the Eskisehir region are shown in Table 2.

Table 1. Mix gradation.

\begin{tabular}{ccc}
\hline $\begin{array}{c}\text { Sieve size } \\
(\mathrm{mm})\end{array}$ & $\begin{array}{c}\text { Limit values } \\
(\%)\end{array}$ & $\begin{array}{c}\text { Percent passing } \\
(\%)\end{array}$ \\
\hline 19.10 & 100.00 & 100.00 \\
12.70 & $90.00-100.00$ & 90.00 \\
9.52 & $50.00-75.00$ & 64.00 \\
4.75 & $25.00-40.00$ & 35.00 \\
2.00 & $20.00-30.00$ & 27.00 \\
0.42 & $12.00-22.00$ & 21.00 \\
0.177 & $9.00-17.00$ & 16.00 \\
0.075 & $8.00-14.00$ & 11.00 \\
\hline
\end{tabular}

\subsection{Bitumen}

B50/70 bitumen class was used in the production stages of all the specimens since it is frequently chosen in many applications of hot mix bituminous binder due to the climatic conditions of Turkey. On the other hand, an elastomeric type of trademarked Styrene/Butadiene/Styrene (SBS) additive was used within the aim of polymer modified bitumen production for the preparation of traditional SMA samples providing the specified criteria in the standard [1]. SBS is considered the most suitable polymer for asphalt modification, although it has economic and technical limitations. The three-dimensional network of SBS enables the bitumen to maintain its elastic properties and performance criteria within a wide temperature range. Granular formed SBS was used, including combinations of $30.0 \%$ of polystyrene/polybutadiene blocks. The modified bitumen was produced in a laboratory by adding $4.0 \%$ of SBS by bitumen weight, as recommended by the manufacturer. A high shear mixing process was realized over a 45.0-minute period with $5000 \mathrm{rpm}$ velocity at $175{ }^{\circ} \mathrm{C}$ according to the proposal of distributor firm and related studies [71]. 
The characteristic properties of SBS modified bitumen and ordinary bitumen with $\mathrm{B} 50 / 70$ penetration are shown in Table 3 for the completion of the fundamental experiments, including ductility, specific gravity and penetrometer Figure 1, Figure 2(a).

Table 2. Physical properties of aggregate.

\begin{tabular}{ccccc}
\hline Size of aggregate & Property & Standards & Specifications Limits & Results \\
\hline & Los Angeles abrasion (\%) & TS EN 1097-2 [35] & $<25.00$ & 24.00 \\
& ASTM C131 [36] & $<14.00$ & 2.90 \\
& Soundness (\%) & TS EN 1367-2 [37] & $<25.00$ & 11.00 \\
\multirow{2}{*}{$19.00-4.75 \mathrm{~mm}$} & ASTM C88 [38] & TS EN 933-3 [39] & -2.00 & 53.10 \\
& Flakiness index (\%) & TS EN 1097-8 [40] & - & 45.00 to 50.00 \\
& Polished stone value & Tayebali et al. [41] & $\leq .77$ & 0.86 \\
& Stripping Resistance (\%) & TS EN 1097-6 [42] & - & 2.78 \\
\multirow{2}{*}{$4.75-0.075 \mathrm{~mm}$} & Water absorption (\%) & ASTM C127 [43] & $\leq 2.00$ & 1.02 \\
\hline \multirow{2}{*}{$0.075-0.00 \mathrm{~mm}$} & Specific gravity & TS EN 1097-6 [42] & - & 2.79 \\
\hline
\end{tabular}

Table 3. Properties of SBS modified B50/70 bitumen.

\begin{tabular}{|c|c|c|c|c|}
\hline \multirow{2}{*}{ Property } & \multirow{2}{*}{ Related standards } & \multirow{2}{*}{ Specifications Limits } & \multicolumn{2}{|c|}{ Result } \\
\hline & & & B50-70 & SBS modified \\
\hline $\begin{array}{c}\text { Penetration at } 25^{\circ} \mathrm{C} \\
(0.1 \mathrm{~mm})\end{array}$ & $\begin{array}{c}\text { TS EN } 1426[46] \\
\text { ASTM D5 [47] }\end{array}$ & $50.00-70.00$ & 65.00 & 49.00 \\
\hline Softening point $\left({ }^{\circ} \mathrm{C}\right)$ & $\begin{array}{c}\text { TS EN } 1427 \text { [48] } \\
\text { ASTM D36 [49] }\end{array}$ & $\begin{array}{c}46.00-54.00 \\
>52.00\end{array}$ & 49.20 & 58.00 \\
\hline Flashing point $\left({ }^{\circ} \mathrm{C}\right)$ & $\begin{array}{c}\text { TS EN ISO } 2592 \text { [50] } \\
\text { ASTM D92 [51] }\end{array}$ & $>230.00$ & 304.00 & 318.00 \\
\hline Specific gravity & $\begin{array}{c}\text { TS EN 15326+A1 [52] } \\
\text { ASTM D70 [53] }\end{array}$ & 1.00 to 1.05 & 1.04 & 1.03 \\
\hline $\begin{array}{c}\text { Loss on heating at } \\
163^{\circ} \mathrm{C}(\%)\end{array}$ & $\begin{array}{l}\text { TS EN 12607-2 [54] } \\
\text { ASTM D6 [55] }\end{array}$ & $\leq 0.50$ & 0.06 & 0.07 \\
\hline
\end{tabular}

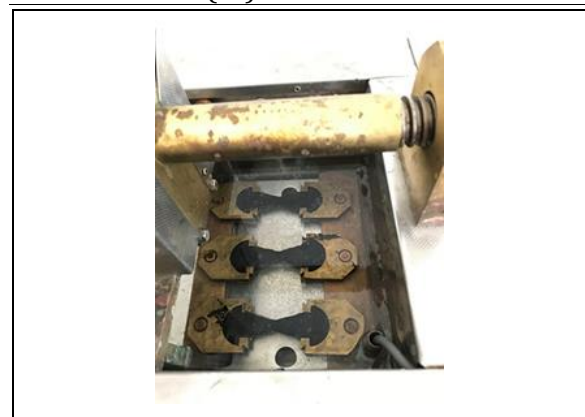

(a)

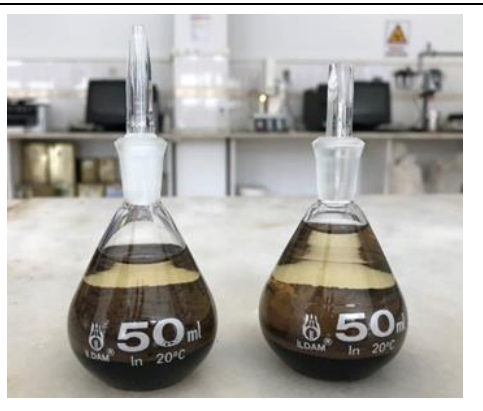

(b)

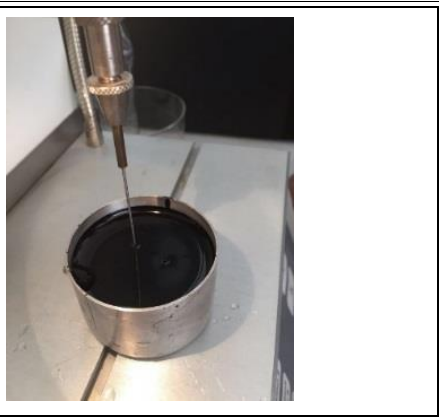

(c)

Figure 1. Basic experiments used for bitumen characteristics. (a): Ductility test. (b): Specific gravity test with pyknometer. (c): Needle penetration test.

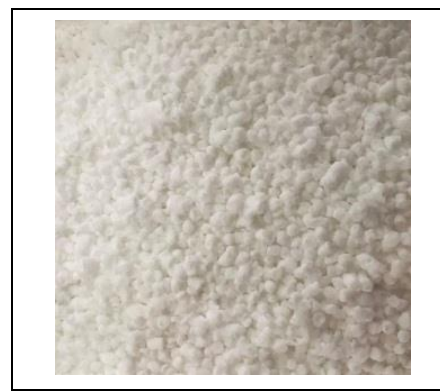

(a)

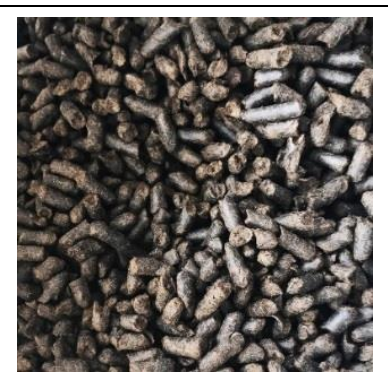

(b)

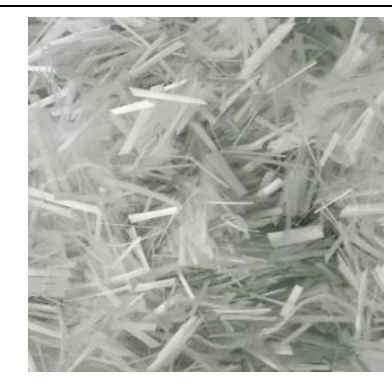

(c)

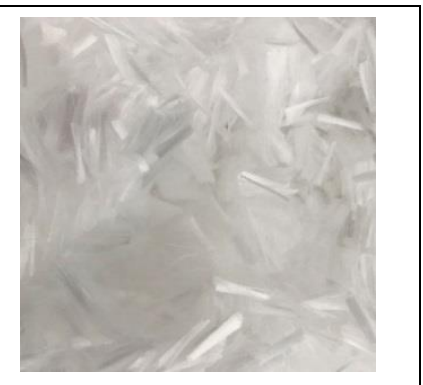

(d)

Figure 2. Used additives in mixtures. (a): SBS. (b): Bitumen impregnated cellulosic fiber. (c): Glass fiber. (d): Polypropylene fiber. 


\section{$2.3 \quad$ Fibers}

GF and PF were used, in terms of cellulosic one, in order to evaluate the effect of fibers on the permanent deformation and crack resistance of SMA. A constant fiber length of $12.0 \mathrm{~mm}$ was selected considering standard sizes on the market and application steps in production. Cellulosic fiber Figure 2(b) is frequently used high performance fiber for the prevention of infiltration of bitumen as well as to increase elasticity and stability. In addition, glass fibers Figure 2(c) obtained from special glass content and petroleum based thermoplastic polymers, known as polypropylene fibers Figure 2(d), are generally used in a similar manner in the transportation industry. The physical and mechanical properties of the abovementioned fibers are shown in Table 4, specified by the supplier.

Table 4. Physical and mechanical properties of fibers provided by the supplier.

\begin{tabular}{ccc}
\hline & \multicolumn{2}{c}{ Type of fiber } \\
Property & Glass & Polypropylene \\
\hline Operating temperature range & -60.00 to & -55.00 to \\
$\left({ }^{\circ} \mathrm{C}\right)$ & 650.00 & 140.00 \\
Melting temperature $\left({ }^{\circ} \mathrm{C}\right)$ & 1120.00 & 165.00 \\
Thermal conductivity & 1.20 to & 0.030 to \\
$\left(\mathrm{W} / \mathrm{m}^{\circ} \mathrm{K}\right)$ & 1.35 & 0.038 \\
Density $\left(\mathrm{g} / \mathrm{cm}^{3}\right)$ & 2.60 & 0.91 \\
Filament diameter $(\mu \mathrm{m})$ & 13.00 to & 22.00 to \\
Modulus of elasticity $(\mathrm{GPa})$ & 15.00 & 28.00 \\
Tensile strength $(\mathrm{MPa})$ & 37.00 & 3.80 \\
& 3400.00 & 400.00 \\
\hline
\end{tabular}

\section{Preparation of specimens}

The requirements mentioned in TSH [1] were taken into consideration in the mixture design of the SMA. The bulk specific gravity of the compacted samples was determined according to the AASHTO T166 [56] method, while the AASHTO T209 [57] method was used during the calculation of the theoretical maximum specific gravity of the loose asphalt mixtures. Cylindrical samples of $100.0 \mathrm{~mm}$ diameter were prepared at bitumen ratios of 5.0\%, 5.5\%, 6.0\%, 6.5\% and $7.0 \%$ in the design of both control mixtures, including pure bitumen and SBS modified mixtures, individually using $0.6 \%$ bitumenimpregnated Viatop 66 type of cellulosic fiber for the bitumen stabilization. All of the specimens were prepared using a Gyratory compactor Figure 3 according to the Superpave mixing procedure proposed by NAPA [58] under 100 gyration, $600.0 \mathrm{kPa}$ pressure and $4.0 \%$ amount of targeted air gap value.

The dry mixing method proposed by Abtahi et al. [59] was used to eliminate the high temperature requirement for melting fibers. The mixtures were prepared at an optimum bitumen ratio (6.5\%) for all fiber added samples, as Morova [60] states that the addition of different fiber ratios with optimum bitumen content give similar results. After the determination of the optimum bitumen content, design mixtures were prepared with different fiber proportions of $0.1 \%, 0.2 \%, 0.4 \%, 0.6 \%$ and $0.8 \%$ by weight of the aggregate. Although the air void in the mixture (VA) and the voids in the mineral aggregate (VMA) are directly proportional to the amount of fiber content, void filled with asphalt (VFA) and density have an inverse proportion as shown in Table 5.

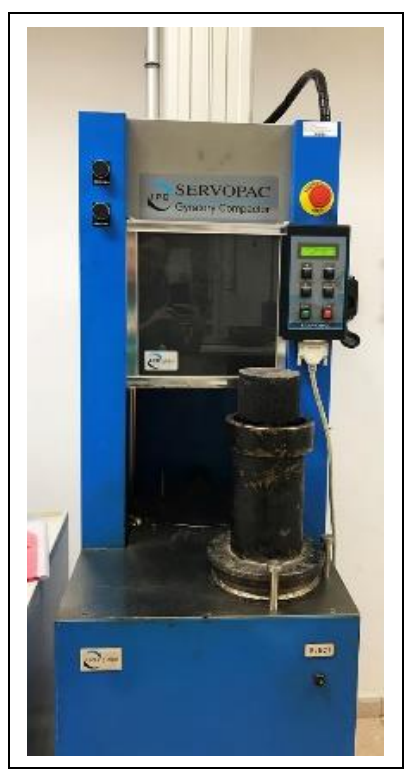

Figure 3. Gyratory compactor.

Table 5. Volumetric properties of control, SBS and fiber modified SMA mixtures.

\begin{tabular}{cccccc}
\hline $\begin{array}{c}\text { Type of } \\
\text { mixture }\end{array}$ & $\begin{array}{c}\text { Amount } \\
\text { of fiber } \\
(\%)\end{array}$ & $\begin{array}{c}\text { VA } \\
(\%)\end{array}$ & $\begin{array}{c}\text { VMA } \\
(\%)\end{array}$ & $\begin{array}{c}\text { VFA } \\
(\%)\end{array}$ & $\begin{array}{c}\text { Density } \\
\left(\mathrm{g} / \mathrm{cm}^{3}\right)\end{array}$ \\
\hline Control & - & 4.01 & 16.30 & 75.4 & 2.509 \\
\hline $\begin{array}{c}\text { SBS } \\
\text { modified }\end{array}$ & - & 4.00 & 16.57 & 75.9 & 2.501 \\
\hline & 0.10 & 3.96 & 16.20 & 75.60 & 2.512 \\
& 0.20 & 4.07 & 16.31 & 75.10 & 2.509 \\
GF & 0.40 & 4.37 & 16.57 & 73.60 & 2.501 \\
& 0.60 & 4.99 & 17.10 & 70.90 & 2.485 \\
& 0.80 & 5.43 & 17.50 & 69.00 & 2.473 \\
\hline PF & 0.10 & 4.10 & 16.34 & 74.90 & 2.508 \\
& 0.20 & 4.17 & 16.40 & 74.60 & 2.506 \\
& 0.40 & 4.26 & 16.48 & 74.20 & 2.504 \\
& 0.60 & 4.35 & 16.52 & 73.70 & 2.506 \\
\hline Specification & 0.80 & 4.55 & 16.73 & 72.80 & 2.496 \\
\hline & - & 3.00 & $\geq 16.00$ & - & - \\
\hline
\end{tabular}

\section{Test methods}

The behavior of the SMA specimens were obtained using the uniaxial static creep test and the repeated creep test (cyclic compression test) using a Universal Testing Machine Figure 4, in order to determine the permanent deformation resistance of mixtures designed to prevent the formation of rutting on the surface. Moreover, a resilient modulus test ( 5 pulse indirect tensile modulus test), moisture susceptibility (water damage) test and draindown (bitumen infiltration or Schellenberger) test were performed to achieve resistance against external effects. 
The most common problem concerning SMA surfaces is known as a draindown of bitumen from the mixture. The mechanical properties of the aforesaid pavement will deteriorate in this case, since aggregate is separately occurring inside the matrix without a required amount of binder. The Schellenberger bitumen draindown test [61],[62] was developed to minimize the infiltration of bitumen. In this test procedure, the mixture is poured into a beaker and placed in an oven for one hour after the prescribed temperature and mixing time has been applied. Then the sample is weighed again and the weight loss is expressed as a percentage in respect to the initial condition.

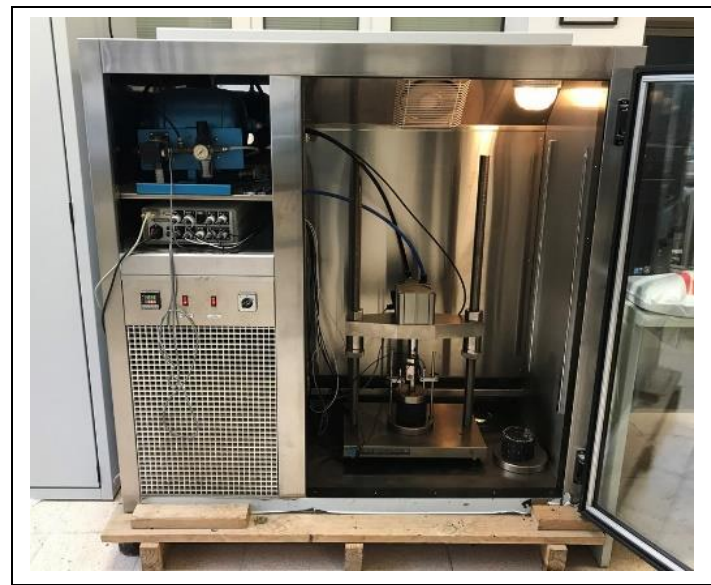

Figure 4. Universal testing machine for creep tests.

In general, a resilient modulus parameter is used with the aim of obtaining the deformation characteristics of asphalt pavements under external loading conditions. This parameter is calculated using the five pulse indirect tensile modulus test [63]. The resilient modulus value is determined at the end of the five conditioning pulses and five load pulses having $2000.0 \mathrm{~ms}$ and $3000.0 \mathrm{~ms}$ periods, respectively. Since the samples are not damaged in this experiment, the same specimens are used in the static creep test.

The uniaxial static creep test is known as a practical method to achieve permanent deformation and creep rigidity of asphalt samples. After the application of preliminary compression pressure has had a sinusoidal behavior along the normal direction, actual external pressure is applied between $5.0 \%$ and $25.0 \%$ of the ultimate value to create a creep phenomenon. The modulus of elasticity can be determined due to measured temporary deformation at this stage. These experiments are performed at $40{ }^{\circ} \mathrm{C}$ for 60 minutes under an axial load of 200.0 $\mathrm{kPa}$ within limitations [6],[64].

In addition, a uniaxial cyclic compression test was performed which has various loading and resting periods which simulates the load patterns caused under vehicular conditions. Test factors, such as uniaxial pressure, loading period and resting period, were selected around $200.0 \mathrm{kPa}, 100.0 \mathrm{~ms}$ and 900.0 $\mathrm{ms}$, respectively, to define the predefined wave form. The strain value and the repeated number of yields were determined at the point where the creep curve passes into the third region [65],[66].

Water can be harmful when penetrating into the asphalt mixture after it is deprived of bond effectiveness according to freeze thaw cycles [67],[68]. Therefore, a water susceptibility test was performed according to the procedure described in the AASHTO T-283 [69] standard that includes conditioned and unconditioned procedures. The conditioning process is defined by the following steps. A freezing temperature of $-18.0^{\circ} \mathrm{C}$ was applied for 16.0 hours Figure 5(a) and thereafter, the specimens were kept in a $60.0{ }^{\circ} \mathrm{C}$ water bath for 2.0 hours Figure 5(b). Lastly, the temperature of the water bath was adjusted to $25.0^{\circ} \mathrm{C}$ for an additional 2.0 hours before indirect tensile tests were conducted.

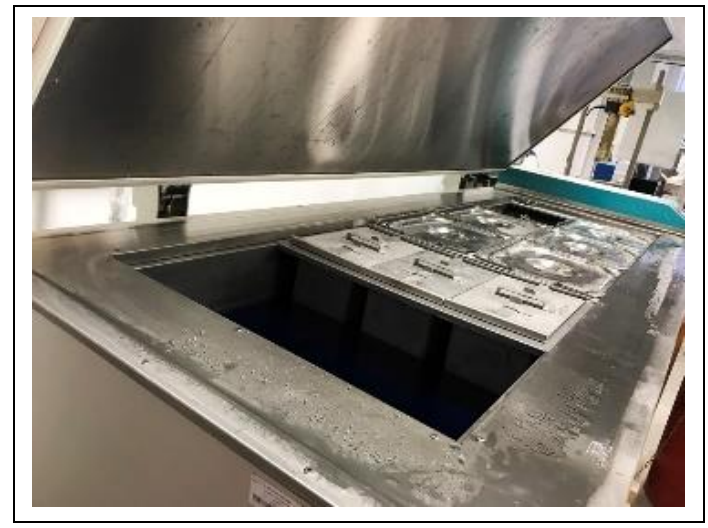

(a)

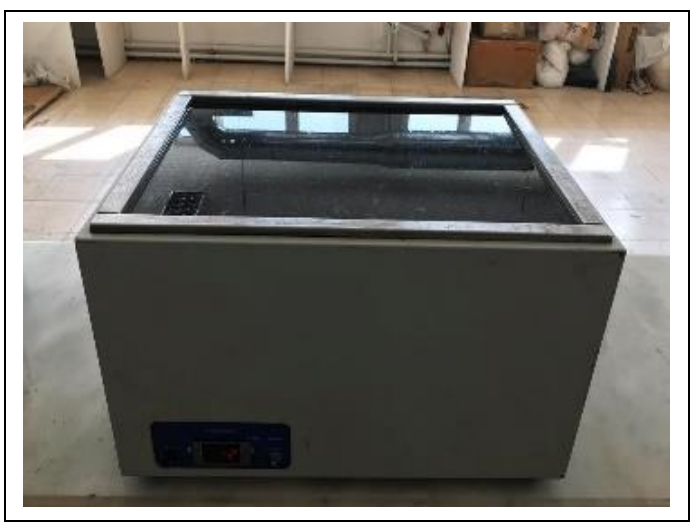

(b)

Figure 5. Conditioning process. (a): Freezing step inside the machine. (b): Heating step inside the water bath.

\section{Results and discussion}

The effects of glass and polypropylene originated fiber additives with amounts of $0.1 \%, 0.2 \%, 0.4 \%, 0.6 \%$ and $0.8 \%$ of the weight of the mixture are presented. On the other hand, the differences between them and the cellulosic fiber added traditional SMA results are also compared with the control specimens.

\subsection{Draindown test}

It can be seen that the amount of infiltration decreases with an increasing amount of fiber additive as expected, and as shown in Figure 6. Each fiber type has a unique draindown distribution due to the change in fiber content. Even though the same results were achieved up to a $0.4 \%$ fiber amount of glass fiber (GF) and polypropylene fiber (PF), bitumen infiltration values were differentiated in the higher additive rates. While the infiltration value of the glass fiber continues to decrease as of $0.6 \%$ fiber content, the polypropylene sample is partially reduced and then increased. This rise is derived from the adhesion of the partially melted polypropylene fiber to the glass beaker surface. The minimum draindown results for glass and polypropylene fiber additives were obtained for $0.8 \%$ and $0.6 \%$ rates, respectively. All of the fiber added specimens ensured the 
minimum draindown value $(0.3 \%)$ recommended in the specification of the Schellenberger method [61],[62]. Despite the fact that cellulosic fiber (CF) has disadvantages in terms of its production and application stages, the greatest resistance against filtration was seen in this case due to its viscosity.

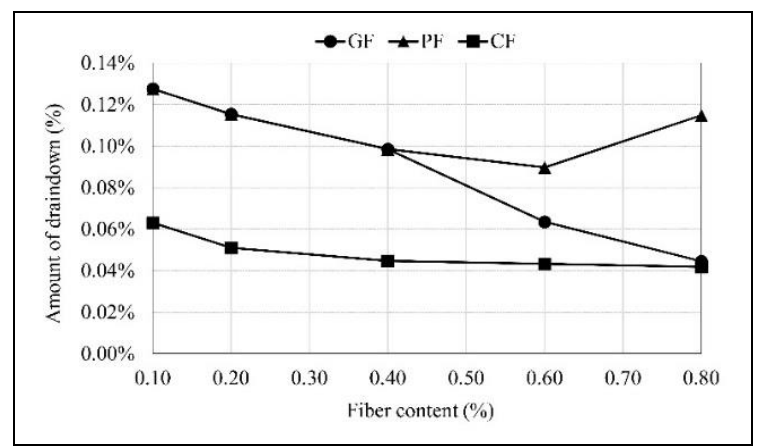

Figure 6. Draindown test results due to the change in fiber content.

\subsection{Resilient modulus}

The resilient modulus, which is calculated by dividing stress by recoverable displacement, provides valuable information about the elasticity properties of asphalt mixtures. An increasing trend is observed with an increase in the amount of glass fiber up to $0.8 \%$, but in the case of polypropylene fiber addition, a bell curved distribution with a peak value of $0.4 \%$ is observed as shown in Figure 7.

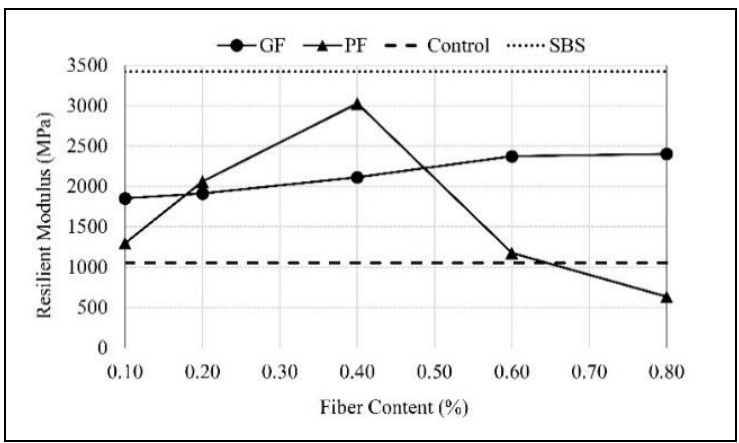

Figure 7. Resilient modulus results due to the change in fiber content.

Therefore, the optimum fiber content for GF can be selected at around $0.6 \%$ in terms of the resilient modulus parameter, because it is almost the same result as the $0.8 \%$ sample. On the other hand, an optimum PF value was obtained at around $0.4 \%$ fiber content, since it shows a sharp drop after this point. These peak resilient modulus values, corresponding to the previously mentioned fiber contents, are greater than the control specimens with a 2.25 and 2.87 -fold increase for GF and PF, respectively. However, lower results were attained with a level of $30.6 \%$ and $11.5 \%$ within the same order if they are compared with SBS added samples.

\subsection{Static creep test}

The fiber modified specimens show much more ductile behavior than both the control and the SBS modified samples related to a significant increase in axial strain values Figure 8. However, this deformation behavior above expected levels creates high strain rates at low load steps rather than having a positive effect. Although a reduction is observed at a $0.4 \% \mathrm{GF}$ addition after approximately 1700 seconds compared to the control sample, a noteworthy rise occurs in other cases during wide-ranging loading processes. It is determined that a sudden displacement increment occurs in the initial loading period after the addition of $0.1 \%$ for GF, even if it is usually seen after a $0.6 \%$ ratio in the case of positively affected additives, such basalt fiber. Mahrez and Karim [14] show that the increase in deformation is caused by the decrease in contact between aggregates due to the addition of glass fiber. This situation becomes more evident with large amounts of glass fiber.

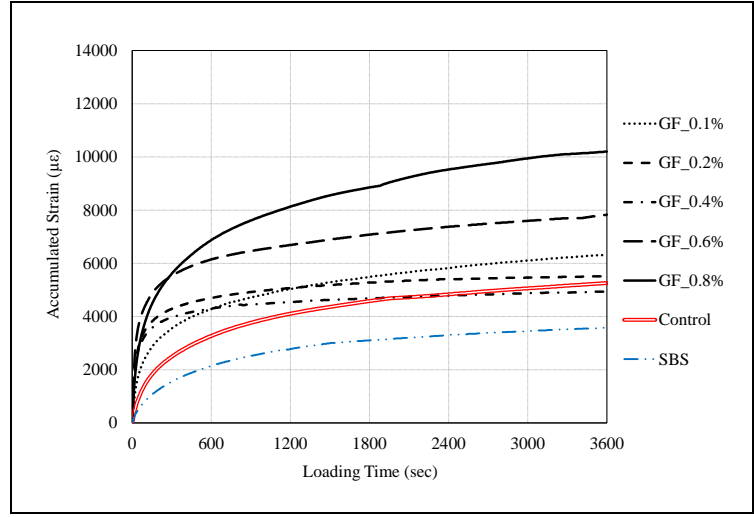

(a)

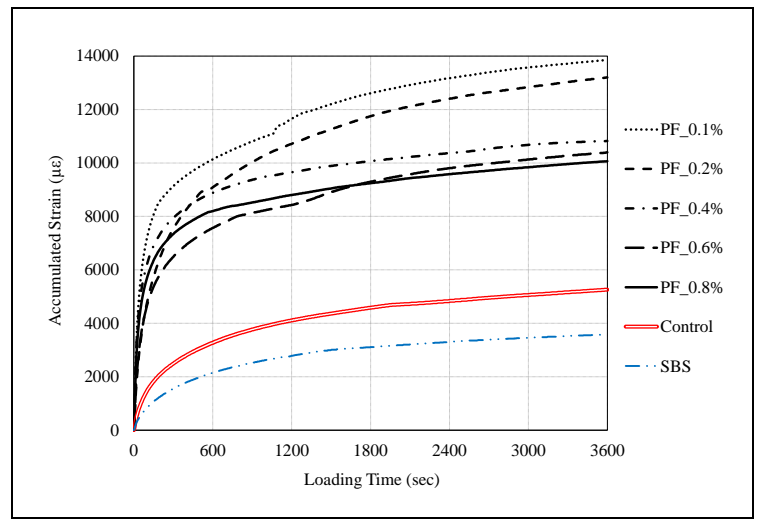

(b)

Figure 8. Static creep test results due to the fiber content. (a): Glass fiber. (b): Polypropylene fiber.

While the lowest axial deformation is obtained in the $0.8 \% \mathrm{PF}$ ratio over a long period, the time-dependent strain curves are extremely close to each other. Therefore, it can be said that the static creep behavior of asphalt mixtures has not been seriously affected by the change in the PF ratio. The most noticeable difference between focused fiber types is the change in strain tendencies during the first loading period especially before 600 seconds. It can clearly be seen that PF added specimens cannot provide expected results within the fiber content increment. This problem is caused by the natural mismatch between the polypropylene fiber and hot asphalt binder, because of the low melting point requirement of fiber according to Huang and White [10].

\subsection{Dynamic creep test}

It can be stated that the fiber added samples have much more ductile failure behavior, since in the static creep tests all of them exhibit higher permanent strain than the SBS and control samples. However, this does not provide a positive effect on the expected level in terms of the creep loading reflecting longterm behavior due to the high level of displacement. This 
unexpected result can be attributed to two main reasons. Firstly, the bitumen passes through the viscous region because the temperature $\left(50^{\circ} \mathrm{C}\right)$ of the test is higher than the softening point of the bituminous binder. Secondly, fiber loses its enhancement effect in the matrix since the experiment was conducted under a uniaxial position without any confinement effect. This situation was effective in the case of the achieving higher deformation values at smaller load cycles. When the curves of all the GF added samples are examined, it can be clearly seen that the permanent strain values are close to each other and also to the control samples Figure 9(a). The results of the specimens consist of PF showing a greater deformation tendency at the lower load repetition numbers compared to those of the control Figure 9(b). These trends confirm the static creep test results, which are not affected by the amount of fiber additive.

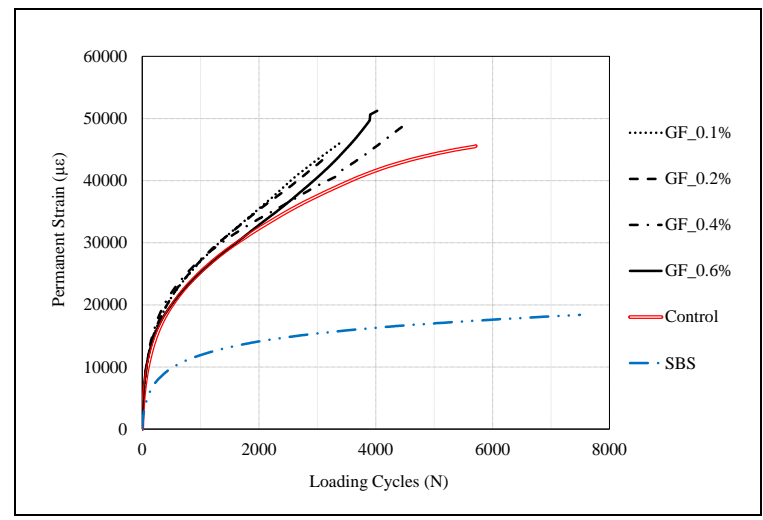

(a)

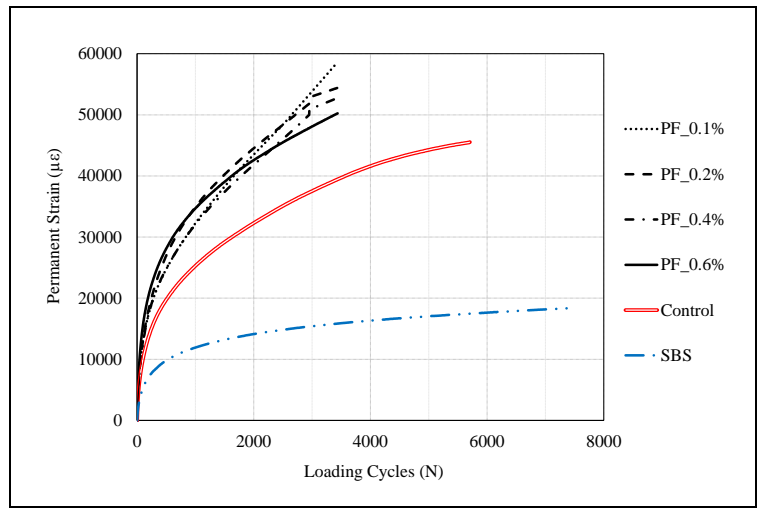

(b)

Figure 9. Dynamic creep test results due to the fiber content. (a): Glass fiber. (b): Polypropylene fiber.

On the other hand, as the softening point of the bitumen was not exceeded during the preparation of the SBS including samples, the related curve has seriously less permanent strain than all of the others. Moreover, it should also be noted that excessive displacement behavior was observed in the $0.8 \%$ fiber included specimens and that meaningless results were obtained in this case due to its heterogeneous matrix. As a result, the permanent deformation curves of the related specimen are removed in Figure 9.

A high degree of bond between the basalt fiber and asphalt binder forms an effective network structure along the micro pores as stated by Gao and $\mathrm{Wu}$ [70]. However, the adherence is reduced by the surface structure of the glass fiber and the partially weaker mechanical properties of the polypropylene inside the matrix, as can be seen in the microscopic images of fibers (Figure 10(a) and (b)). Therefore, high unit deformation behavior most likely occurs under both static and dynamic loading conditions due to these defects.

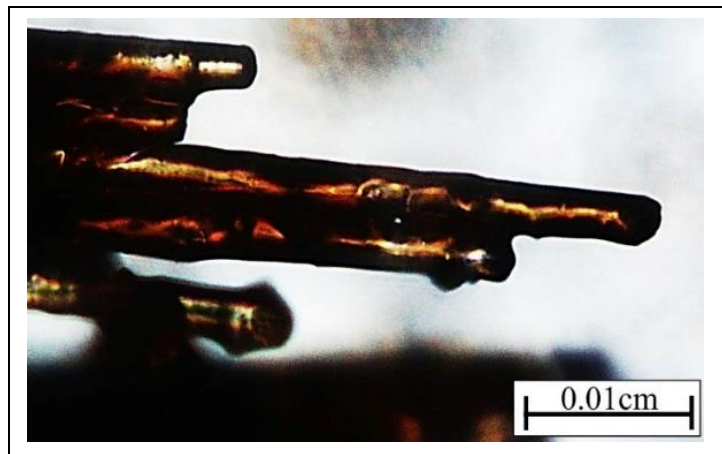

(a)

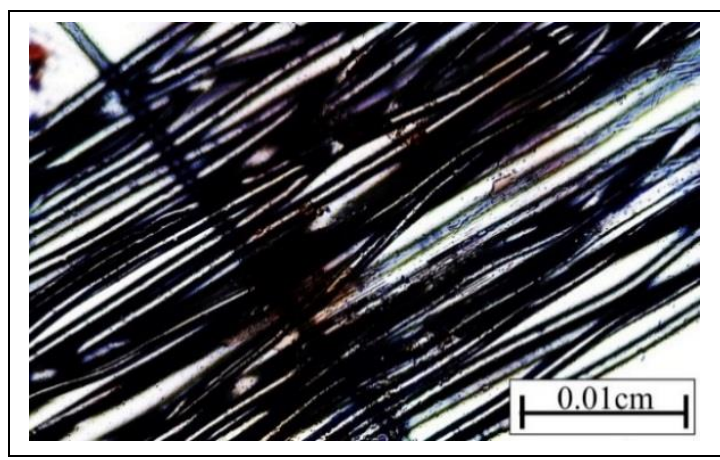

(b)

Figure 10. Microscopic images. (a): Glass fiber. (b): Polypropylene fiber (20x magnification factor).

\subsection{Moisture susceptibility test}

The indirect tensile strength values of the fiber modified specimens are shown in Figure 11 within the scope of the moisture susceptibility test. In general, strength increased to a certain value and then decreased with an increase in fiber ratios. This reduction has a sharp transition in the glass fiber, but is soft in the polypropylene fiber. Although the maximum strength was obtained at around a $0.2 \%$ ratio for the PF added specimens in the unconditioned case, this peak value shifted to the $0.4 \%$ one. On the other hand, the ultimate values of the GF specimens were observed at around $0.6 \%$ in both cases. Most of the fiber modified specimens were located between the control specimens and the SBS specimen. Only $0.6 \%$ of the GF added sample provided great enhancement, even more than SBS sample. This suggests that the glass and polypropylene fibers are effective in reducing fatigue and low temperature cracking in terms of the tensile strength of the SMA mixtures. Similarly,

Previous studies [18],[19],[21],[22] conducted on modified mixtures indicate that tensile strength and low temperature crack resistance are significantly increased by the addition of fibers at low temperatures. While the change in amount of GF is consistent with the resilient modulus results, the PF fiber samples show a completely different trend contrary to the resilient modulus. This can be attributed to a loss of the form of $\mathrm{PF}$ in the asphalt mixture, due to its melting temperature and high temperature sensitivity. 


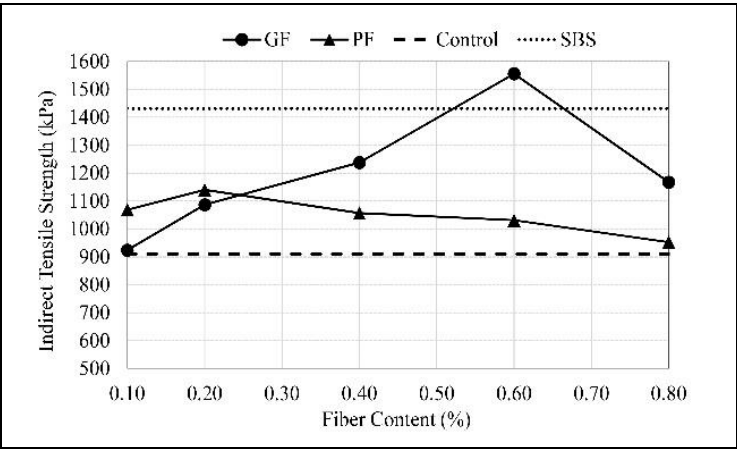

(a)

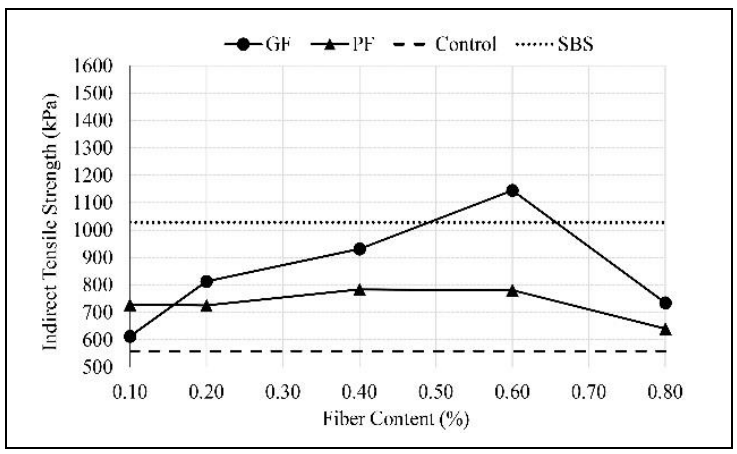

(b)

Figure 11. Indirect tensile strength of specimens in the cases of; (a): Unconditioned process, (b): Conditioned process.

Moreover, the numerical index of resistance against water effect (TSR) was calculated with the ratio between indirect tensile strength (ITS) values of the conditioned and unconditioned specimens as given in Equation (1), Figure 12.

Although typical TSR values range from 0.70 to 0.90 , the limitation of General Directorate of Highways of Turkey [1] cannot be reached. The results for all fibers with $0.4 \%$ and $0.6 \%$ additive ratios are extremely close to each other and the highest value is obtained in the $0.4 \% \mathrm{GF}$ contained samples. This value is more than both control samples and the SBS modified samples with a ratio of $14.0 \%$ and $3.5 \%$, respectively. These results show that a reduction in adhesion between the aggregate and bituminous binder arising from the effect of water can be minimized by the distribution of the appropriate fiber content in the bitumen matrix. However, if the aforesaid improvement is insufficient, it is important to investigate the design with stripping prevention agents.

$$
\operatorname{TSR}(\%)=I T S_{\text {conditioned }} / I T S_{\text {unconditioned }}
$$

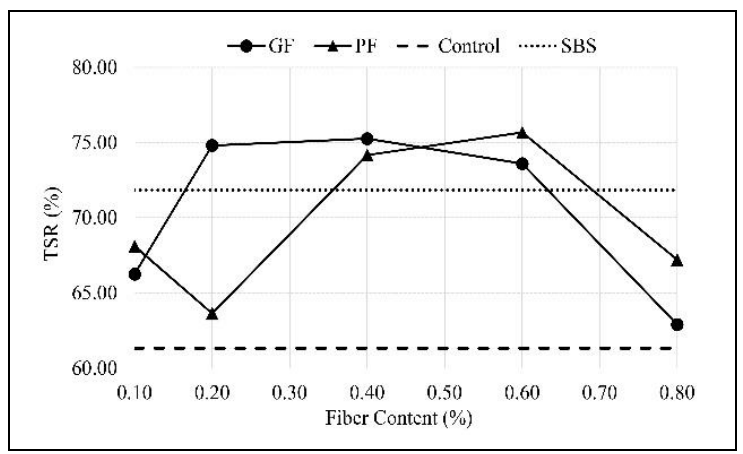

Figure 12. Tensile strength ratio (TSR) for asphalt mixtures of various fiber types and content.

\section{Conclusions}

This paper deals with the evaluation of glass fiber (GF) and polypropylene fiber (PF) usage within a mix modification by the dry mixing method instead of bitumen modification and cellulosic fiber usage. The following results can be drawn based on experimental studies concerning the design performance of SMA mixtures.

The draindown results of mixtures decrease with an increase in the amount of fiber, except for $0.8 \%$ PF. All of the fiber modified specimens are determined below a $0.3 \%$ value, which is the maximum infiltration ratio mentioned in the related specification. Therefore, it is appropriate to select an optimum fiber amount of between $0.6 \%$ and $0.8 \%$ rates. These fiber types can be confidently used as an alternative to cellulosic fiber in terms of resistance against any draindown effect.

When the fiber additive increases in the mixture, the resilient modulus values, that reflect the elasticity properties, tend to increase up to an optimum value and, thereafter, starts to decrease. These peak values of $0.6 \%$ for GF and $0.4 \%$ for PF are approximately 2.5 times higher than the control samples, although they are still lower than the SBS doped samples.

Only the $0.4 \%$ GF contained specimens provide an improvement of $10.0 \%$ in the final loading time according to the results of the uniaxial static creep test. For the others, it is not even close to the control sample and cannot be compared to the SBS modified ones. This unexpected result can be attributed to the following characteristics of the chosen fibers. A high level of axial deformations were seen in the initial loading period with respect to a decrease in the adhesion strength of the GF in the matrix due to the smooth surface structure. In addition, PF reduced the workability of the blends due to the melting temperature and high temperature sensitivity and cannot provide the expected effect by losing its form.

While the GF modified samples are close to the control sample results, the PF added samples tend to be a higher permanent strain in terms of dynamic creep behavior. However, these results are lower than the expected levels in either event. The reason for this can be that the fibers lose their effect in the matrix due to the softening point of bitumen and the absence of confinement pressure. On the other hand, as the softening point value of bitumen is not exceeded in the SBS added specimens, they show much less strain values in terms of creep tests.

Although the trends of the indirect tensile test, with respect to moisture effect and stiffness tests, change according to the amount of GF were compatible, the indirect tensile strength was not seriously affected by the amount of PF, unlike the resilient modulus test results.

When considering the tensile strength ratio, around $75.0 \%$ value (even above the SBS samples) was obtained for the GF and $\mathrm{PF}$ addition with the fiber content ranging between $0.2-0.4 \%$ and $0.4-0.6 \%$, respectively.

Consequently, certain low-level results were encountered due to the brittle structure and surface properties of the GF, as well as the temperature sensitivity and partial low tensile strength of the PF. Therefore, bitumen modification is recommended for glass and polypropylene fibers instead of a mixture modification during the fiber addition process. Moreover, higher properties can be obtained by the use of fibers with much higher characteristics, such as basalt originated ones. 


\section{Author contribution statements}

In the scope of this study, the Burak EVIRGEN and Asena KARSLIOĞLU in the formation of the idea, design, literature review, collecting data, assessment of obtained results and writing; Altan ÇETIN and Ahmet TUNCAN in the formation of the idea, writing and checking the article in terms of content were contributed.

\section{Ethics committee approval and conflict of interest statement}

There is no need to obtain permission from the ethics committee for the article prepared.

There is no conflict of interest with any person/institution in the article prepared.

\section{References}

[1] General Directorate of Highways of Turkey. "Technical Specification of Highways". Ankara, Turkey, 2013.

[2] Brown ER, Haddock JE, Mallick RB, Lynn TA. "Development of a mixture design procedure for stone matrix asphalt (SMA)". National Center for Asphalt Technology, Auburn, USA, Scientific Report, NCAT97-03, 1997.

[3] Blazejowski K. Stone Matrix Asphalt: Theory and Practice. $1^{\text {st }}$ ed. Boca Raton, USA, CRC Press, Taylor \& Francis Group 2011.

[4] Nejad FM, Aflaki E, Mohammadi MA. "Fatigue behavior of SMA and HMA mixtures". Construction and Building Materials, 24(7), 1158-1165, 2010.

[5] Ozen H, Aksoy A, Tayfur S, Celik F. "Laboratory performance comparison of the elastomer-modified asphalt mixtures". Building and Environment, 43(7), 1270-1277, 2008.

[6] National Asphalt Pavement Association. "Designing and constructing SMA mixtures: State-of-the-practice". Maryland, USA, Scientific Report, Quality Improvement Series 122, 2002.

[7] Behbahani H, Nowbakht S, Fazaeli H, Rahmani J. "Effect of fiber type and content on the rutting performance of stone mastic asphalt". Journal of Applied Sciences, 9(10), 1980-1984, 2009.

[8] Wu S, Ye Q, Li N. "Investigation of rheological and fatigue properties of asphalt mixtures containing polyester fibers". Construction and Building Materials, 22(10), 2111-2115, 2008

[9] Lee SJ, Rust JP, Hamouda H, Kim YR, Borden RH. "Fatigue cracking resistance of fiber-reinforced asphalt concrete". Textile Research Journal, 75(2), 123-128, 2005.

[10] Huang H, White TD. "Dynamic properties of fibre-modified overlay mixture". Transportation Research Record, 1545(1), 98-104, 1996.

[11] Mahrez A, Karim MR, Katman HY. "Fatigue and deformation properties of glass fiber reinforced bituminous mixes". Journal of the Eastern Asia Society for Transportation Studies, 6, 997-1007, 2005.

[12] Fakhri M, Hosseini SS. "Laboratory evaluation of rutting and moisture damage resistance of glass fiber modified warm mix asphalt incorporating high RAP proportion". Construction and Building Materials, 134, 626-640, 2017.
[13] Abtahi SM, Esfandiarpour S, Kunt M, Hejazi SM, Ebrahimi MG. "Hybrid reinforcement of asphalt-concrete mixtures using glass and polypropylene fibers". Journal of Engineered Fibers and Fabrics, 8(2), 25-35, 2013.

[14] Mahrez A, Karim MR. "Fatigue characteristics of stone mastic asphalt mix reinforced with fiber glass". International Journal of the Physical Sciences, 5(12), 1840-1847, 2010.

[15] Mahrez A, Karim MR, Katman HY. "Prospect of using glass fiber reinforced bituminous mixes". Journal of the Eastern Asia Society for Transportation Studies, 5, 794-807, 2003.

[16] Hejazi SM, Abtahi SM, Sheikhzadeh M, Semnani D. "Introducing two simple models for predicting fiberreinforced asphalt concrete behavior during longitudinal loads". Journal of Applied Polymer Science, 109(5), 2872-2881, 2008.

[17] Najd A, Chao Z, Ying G. "Experiments of fracture behavior of glass fiber reinforced asphalt concrete". Journal of Chang'an University (Natural Science Edition), 25(3), 28-32, 2005.

[18] Singha K. "A short of review on basalt fiber". International Journal of Textile Science, 1, 19-28, 2012.

[19] Liu ZH, Chen CY, Qin RJ, Zou XT. "Research to performance of basalt fibre strengthen SBS modified asphalt mixture". Advanced Materials Research, 446-449, 191-195, 2012.

[20] Zheng Y, Cai Y, Zhang G, Fang H. "Fatigue property of basalt fiber-modified asphalt mixture under complicated environment". Journal of Wuhan University of TechnologyMaterials Science Edition, 29(5), 996-1004, 2014.

[21] Wang D, Wang L, Gu X, Zhou G. "Effect of basalt fiber on the asphalt binder and mastic at low temperature". Journal of Materials in Civil Engineering, 25(3), 355-364, 2013.

[22] Zhang X, Gu X, Lv J, Zhu Z, Zou X. "Numerical analysis of the rheological behaviors of basalt fiber reinforced asphalt mortar using ABAQUS". Construction and Building Materials, 157, 392-401, 2017.

[23] Zhang X, Gu X, Lv J, Zou X. "3D numerical model to investigate the rheological properties of basalt fiber reinforced asphalt-like materials". Construction and Building Materials, 138, 185-194, 2017.

[24] Qin X, Shen A, Guo Y, Li Z, Lv Z. "Characterization of asphalt mastics reinforced with basalt fibers". Construction and Building Materials, 159, 508-516, 2018.

[25] Song PS, Hwang S, Sheu BC. "Strength properties of nylonand polypropylene-fiber-reinforced concretes". Cement and Concrete Research, 35(8), 1546-1550, 2005.

[26] Yao W, Li J, Wu K. "Mechanical properties of hybrid fiber-reinforced concrete at low fiber volume fraction". Cement and Concrete Research, 33(1), 27-30, 2003.

[27] Information and Technology Educators of Minnesota. "Standard Specification for Asphalt Concrete-High Stress Using Polypropylene Fibers". Roseville, USA, ITEM 400HS, 1998.

[28] Labib M, Maher A. "Recycled Plastic Fibers for Asphalt Mixtures". Federal Highway Administration, Washington, USA, Scientific Report, 2000-04, 1999.

[29] Rajyaguru D, Kumar R, Mishra CB. "Contribution of polypropylene fibers in modification of vg30 bituminous mix". International Journal of Engineering Sciences \& Research Technology, 5(4), 877-882, 2016. 
[30] Nekhoroshev VP, Nekhorosheva AV, Popov EA, Gossen LP. "Influence of the products of chemical modification of atactic polypropylene on properties of bitumen binders". Russian Journal of Applied Chemistry, 74(8), 1368-1373, 2001.

[31] Ai AH, Yi-Qiu T. "Long-term aging of polypropylene asphalt paving mixtures". $26^{\text {th }}$ Southern African Transport Conference, Pretoria, South Africa, 9-12 July 2007.

[32] Sadeque M, Patil KA. "Rheological properties of recycled low density polyethylene and polypropylene modified bitumen". International Journal of Advanced Technology in Civil Engineering, 2(2), 24-26, 2013.

[33] Ahmad M, Ayob M. "Improvement of road pavement infrastructure by using polyethylene terephthalate \& polypropylene". International Journal of Advances in Mechanical and Civil Engineering, 2(3), 126-134, 2015.

[34] Moubark S, Khodary F, Othman A. "Evaluation of mechanical properties for polypropylene modified asphalt concrete mixtures". International Journal of Scientific Research and Management. 5(12), 7797-7801, 2017.

[35] Turkish Standards Institute. "Tests for Mechanical and Physical Properties of Aggregates - Part 2: Methods for the Determination of Resistance to Fragmentation". Ankara, Turkey, TS EN 1097-2, 2015.

[36] American Society for Testing Materials. "Standard Test Method for Resistance to Degradation of Small-Size Coarse Aggregate By Abrasion And Impact In The Los Angeles Machine". West Conshohocken, USA, ASTM C131/C131M-14, 2014.

[37] Turkish Standards Institute. "Tests for Thermal and Weathering Properties of Aggregates-Part 2: Magnesium Sulfate Test". Ankara, Turkey, TS EN 1367-2, 2010.

[38] American Society for Testing Materials. "Standard Test Method for Soundness of Aggregates by Use of Sodium Sulfate or Magnesium Sulfate". ASTM C88/C88M-18, ASTM International, West Conshohocken, 2018.

[39] Turkish Standards Institute. "Tests for geometrical Properties of Aggregates-Part 3: Determination of Particle Shape-Flakiness Index". Ankara, Turkey, TS EN 933-3, 2012.

[40] Turkish Standards Institute. "Tests for Mechanical and Physical Properties of Aggregates-Part 8: Determination of the Polished Stone Value". Ankara, Turkey, TS EN 1097-8, 2010.

[41] Tayebali AA, Kusam A, Bacchi C. "An innovative method for interpretation of asphalt boil test". Journal of Testing and Evaluation, 46(4), 1622-1635, 2018.

[42] Turkish Standards Institute. "Tests for Mechanical and Physical Properties of Aggregates-Part 6: Determination of Particle Density and Water Absorption". Ankara, Turkey, TS EN 1097-6, 2013.

[43] American Society for Testing Materials. "Standard Test Method for Relative Density (specific gravity) and Absorption of Coarse Aggregate". West Conshohocken, USA, ASTM C127-15, 2015.

[44] American Society for Testing Materials. "Standard Test Method for Relative Density (specific gravity) and Absorption of Fine Aggregate". West Conshohocken, USA, ASTM C128-15, 2015.

[45] Turkish Standards Institute. "Tests for Mechanical and Physical Properties of Aggregates- Part 7: Determination of the Particle Density of Filler-Pyknometer Method". Ankara, Turkey, TS EN 1097-7, 2009.
[46] Turkish Standards Institute. "Bitumen and Bituminous Binders-Determination of Needle Penetration". Ankara, Turkey, TS EN 1426, 2015.

[47] American Society for Testing Materials. "Standard Test Method for Penetration of Bituminous materials". West Conshohocken, USA, ASTM D5/D5M-13, 2013.

[48] Turkish Standards Institute. "Bitumen and Bituminous Binders-Determination of the Softening Point-Ring and Ball Method". Ankara, Turkey, TS EN 1427, 2015.

[49] American Society for Testing Materials. "Standard Test Method for Softening Point of Bitumen (ring-and-ball apparatus)". West Conshohocken, USA, ASTM D36/D36M$14 \mathrm{e} 1,2014$

[50] Turkish Standards Institute. "Petroleum and Related Products-Determination of Flash and Fire Points-Cleveland Open Cup Method". Ankara, Turkey, TS EN ISO, 2592, 2017.

[51] American Society for Testing Materials. "Standard Test Method for Flash and Fire Points by Cleveland Open Cup Tester". West Conshohocken, USA, ASTM D92-18, 2018.

[52] Turkish Standards Institute. "Bitumen and Bituminous Binders-Measurement of Density and Specific Gravity-Capillary-Stoppered Pyknometer Method". Ankara, Turkey, TS EN 15326+A1, 2010.

[53] American Society for Testing Materials. "Standard Test Method for Density of Semi-Solid Asphalt Binder (pycnometer method)". West Conshohocken, USA, ASTM D70-18, 2018.

[54] Turkish Standards Institute. "Bitumen and Bituminous Binders-Determination of the Resistance to Hardening Under Influence of Heat and Air - Part 2: TFOT method". Ankara, Turkey, TS EN 12607-2, 2015.

[55] American Society for Testing Materials, "Standard Test Method for Loss on Heating of oil and Asphaltic Compounds". West Conshohocken, USA, ASTM D6/D6M-95, 2018.

[56] American Association of State Highway and Transportation Officials "Standard Method of Test for Bulk Specific Gravity (Gmb) of Compacted Hot mix Asphalt (Hma) Using Saturated Surface-Dry Specimens". Washington, USA, AASHTO T166, 2016.

[57] American Association of State Highway and Transportation Officials. "Standard method of test for theoretical maximum specific gravity ( $\mathrm{Gmm}$ ) and density of hot mix asphalt (Hma)". Washington, USA, AASHTO T209, 2012.

[58] National Asphalt Pavement Association. "HMA Pavement Mix Type Selection Guide". Maryland, USA, Scientific Report, Information Series 128, 2001.

[59] Abtahi SM, Sheikhzadeh M, Hejazi SM. "Fiber-Reinforced asphalt-concrete-a review". Construction and Building Materials, 24(6), 871-877, 2010.

[60] Morova N. "Investigation of usability of basalt fibers in hot mix asphalt concrete". Construction and Building Materials, 47, 175-180, 2013.

[61] Turkish Standards Institute. "Bituminous Mixtures-Test Methods-Part 18: Binder drainage". Ankara, Turkey, TS EN 12697-18, 2018.

[62] American Association of State Highway and Transportation Officials. "Standard Method of Test for Determination of Draindown Characteristics in Uncompacted Asphalt Mixtures". Washington, USA, AASHTO T305, 2014. 
[63] Turkish Standards Institute. "Bituminous Mixtures-Test Methods for Hot Mix Asphalt-Part 26: Stiffness". Ankara, Turkey, TS EN 12697-26, 2012.

[64] Brown ER, Kandhal PS, Zhang J. "Performance Testing for Hot Mix Asphalt". National Center for Asphalt Technology, Auburn, USA, Scientific Report, NCAT 01-05, 2001.

[65] Witczak MW, Kaloush K, Pellinen T, El-Basyouny M, Von Quintus H. "Simple Performance Test for Superpave Mix Design". National Cooperative Highway Research Program, Washington, USA, NCHRP 465, 2002.

[66] Zhou F, Scullion T, Sun L. "Verification and modeling of three-stage permanent deformation behavior of asphalt mixes". Journal of Transportation Engineering, 130(4), 486-494, 2004.

[67] Ahmedzade P, Yilmaz M. "Effect of polyester resin additive on the properties of asphalt binders and mixtures". Construction and Building Materials, 22(4), 481-486, 2008.
[68] Shen DH, Wu CM, Du JC. "Performance evaluation of porous asphalt with granulated synthetic lightweight aggregate". Construction and Building Materials, 22(5), 902-910, 2008.

[69] American Association of State Highway and Transportation Officials. "Standard Method of Test for Resistance of Compacted Asphalt Mixtures to Moisture-Induced Damage". Washington, USA, AASHTO T283, 2014

[70] Gao C, Wu W. "Using ESEM to analyze the microscopic property of basalt fiber reinforced asphalt concrete". International Journal of Pavement Research and Technology, 11(4), 374-380, 2018.

[71] Fernandes MRS, Forte MMC, Leite LFM. "Rheological evaluation of polymer-modified asphalt binders". Materials Research, 11(3), 381-386, 2008. 